\title{
Fruit Traits of Pepper Genotypes Originating from Open Pollination
}

\author{
Dario Danojević · Slađana Medić-Pap · Aleksandra Savić · Janko Červenski
}

Institute of Field and Vegetable Crops, Maksima Gorkog 30, 21000 Novi Sad, Serbia

\begin{abstract}
Summary: In different regions of Serbia people consume pepper fruits with various shapes, sizes and colors. In southern Serbia consumers prefer longer fruits, while in the northern part shorter fruits are more preferred. The aim of this paper was to evaluate four pepper genotypes $(355,356,357$, and 358$)$ with shorter fruits originating from open pollination. These genotypes were compared with the parental line 354 with longer fruits. The fruits were harvested in technological maturity. Fruit (length, width, weight, and index), locule number, pericarp thickness, total soluble solids and fruit yield per plant were evaluated. The line 354 had the longest fruits $(14.46 \mathrm{~cm})$. Genotype 358 had the highest pericarp thickness $(5.8 \mathrm{~mm})$, while the genotype 357 had the highest fruit weight $(105 \mathrm{~g})$. Based on the evaluated traits, genotype 357 will be used for further selection because of higher fruit weight, and genotype 358 because of a thicker pericarp.

Key words: fruit length, fruit traits, genotyping, open pollination, pepper, pericarp thickness
\end{abstract}

\section{Introduction}

In most cultivated species, the loss of genetic variability began with the process of domestication (Tang et al., 2010). In contrast, thousands of years of human selection in different conditions and growing methods resulted in the development of new mutations and gene combinations that are of agricultural importance, with low probability to occur under the pressure of natural selection. Lefebvre et al. (1993) noted that the species $C$. annum is very variable in relation to other self-pollinated crops.

Although the pepper is self-pollinated, previous studies showed cross-pollination performed by bees (Cruz et al., 2005; Greco et al., 2011). According to Serrano \& Guerra-Sanz (2006), plants use various mechanisms to promote cross pollination. While in pepper flowers insects are not necessary for pollination, plants have developed different traits that have enabled maximized yields and quality.

The differences in quantitative traits are useful for the development of descriptors and the identification of variety. Since the quantitative traits have great agricultural importance, they are also significant in breeding programs (Panther et al., 2004). Geleta et al.

Corresponding author:

dario.danojevic@ifvens.ns.ac.rs

Acknowledgement:

This study was supported by Ministry of Education, Science and Technological Development of the Republic of Serbia, under the project TR 31030
(2005) found that the morphological fruit traits and AFLP markers lead to separation of pepper genotypes. Significant positive correlation between the morphological traits and AFLP markers indicated that the difference in AFLP distances tend to reflect the morphological differences. Lefebvre et al. (2001) suggest that the relationship between molecular distance and phenotypic traits in inbred lines with different phenotypes could also distinguished by their AFLP markers. Therefore, the genotypes can easily be distinguished using only phenotypic traits (Geleta et al., 2005).

Smith \& Basavaraja (2005) and Bharadwaj et al. (2007) found that during selection of peppers very important traits are: fruit weight, fruit length, and fruit diameter, because they affect the yield directly. The pericarp thickness and total soluble solids content are important characteristics essential for fruit quality for fresh consumption and for processing.

Pepper (C. annum ) is one of the major vegetable crops in Serbia. In different regions of Serbia people consume pepper fruits with various shapes, sizes and colors. In southern Serbia consumers prefer longer fruits, while in the northern part shorter fruits are more preferred. In the assortment of Institute of Field and Vegetable Crops, Novi Sad (IFVCNS) there is no pepper variety with conic and hanging fruits. The aim of this paper was to evaluate some important fruit traits in four pepper genotypes with shorter fruits-conic type (355, 356, 357, and 358) originating from open pollination. These genotypes were compared with the parental line 354 with longer fruits of kapia type. 


\section{Materials and Methods}

Genotypes 355, 356, 357, and 358 originated from the parental line 354 (Figure 1). The inbred line 354 (S$46 / 04$ in IFVCNS collection) is a high yielding, light green, sweet kapia pepper. Fruit length is about $15 \mathrm{~cm}$ and fruit width is about $5 \mathrm{~cm}$. In 2012 and 2013 we noticed four plants with different fruit length and width. Other plant traits such as plant height, leaf and fruit color were the same. Because of high yield potential of line 354 we took seeds from open pollinated plants for further evaluation. The seedlings were produced in a greenhouse without heating. Plants were transplanted on 30 May 2014 in the open field of Institute of Field and Vegetable Crops Novi Sad (Rimski Šančevi) Serbia, with three replications (20 plants in each repetition). The distances between plants were $70 \mathrm{~cm} \times 25 \mathrm{~cm}$. Common agricultural practices for peppers were applied and plants were irrigated by sprinkling. The fruits were harvested in technological maturity three times. Fifteen fruits (five per replication) per genotype were analyzed from the second harvest. Fruit (length, width, weight, and index), locule number, pericarp thickness, soluble solids and yield per plant were evaluated. Data were collected according to Descriptor for Capsicum (IPGRI, AVRDC \& CATIE, 1995). Total soluble solids Brix (TSS) were measured from each separate fruit by Digital Refractometer. Data were processed in software Statistica 12.0 (StatSoft, Dell Inc., USA) using onefactorial analysis of variance, with Duncan's multiple test interval at a significance level of 0.05. Pearson correlation coefficients were determined at the significance level of 0.05 and 0.01 probability. Coefficient of variation (CV) was also calculated.

\section{Results and Discussion}

The maternal line 354 had the longest fruit (14.46 $\mathrm{cm})$, while the length of other genotypes ranged from $10.54 \mathrm{~cm}$ to $11.56 \mathrm{~cm}$ (Figure 2). Genotypes 354 and 355 had the narrowest fruit, while genotype 357 had the widest fruit $(5.96 \mathrm{~cm})$, which resulted in the smallest fruit index (1.94). Genotype 358 had the highest pericarp thickness $(5.8 \mathrm{~mm})$. Genotype 357 had the highest fruit weight $(105 \mathrm{~g})$, followed by maternal line 354, while the other three genotypes had the lowest fruit weight. TSS varied slightly among the genotypes. Genotype 355 had the lowest TSS content, except in comparison to the genotype 356. Among the genotypes there was no significant difference in the fruit yield, so these data were not shown. This could be explained by the strong influence of the maternal line.

To determine the degree of relationship between the evaluated traits, researchers usually use a simple correlation analysis (Cankaya \& Kayaalp, 2007). In our study we found a positive correlation between fruit weight and pericarp thickness (Table 1). The same results were reported by Lannes et al. (2007) in the species $C$. chinense. Fruits with thicker pericarp are less susceptible to injuries during postharvest manipulation in transport and selling.
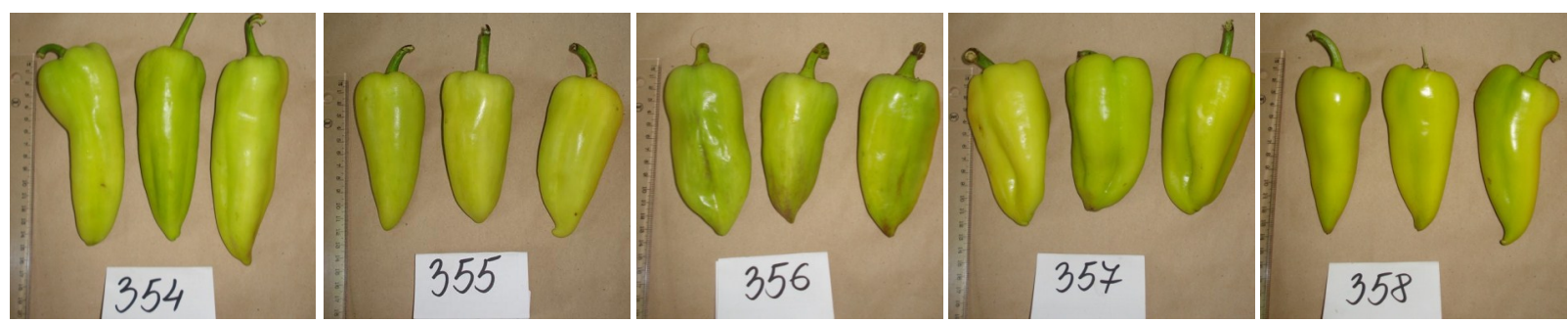

Figure 1. Evaluated pepper genotypes

Table 1. Coefficient of correlation between evaluated pepper fruit traits

\begin{tabular}{|c|c|c|c|c|c|}
\hline Trait & Fruit width & Pericarp thickness & Locule number & Fruit weight & TSS \\
\hline Fruit length & -0.18 & -0.09 & -0.12 & $0.43^{* *}$ & 0.19 \\
\hline Fruit width & & $0.42 * *$ & 0.00 & $0.60^{* *}$ & $0.40^{* *}$ \\
\hline Pericarp thickness & & & -0.21 & $0.30^{* *}$ & $0.25^{*}$ \\
\hline Locule number & & & & $0.29 *$ & 0.10 \\
\hline Fruit weight & & & & & $0.51^{* *}$ \\
\hline
\end{tabular}

$*$ and $* *$ significant at 0.05 and 0.01 probability level, respectively 

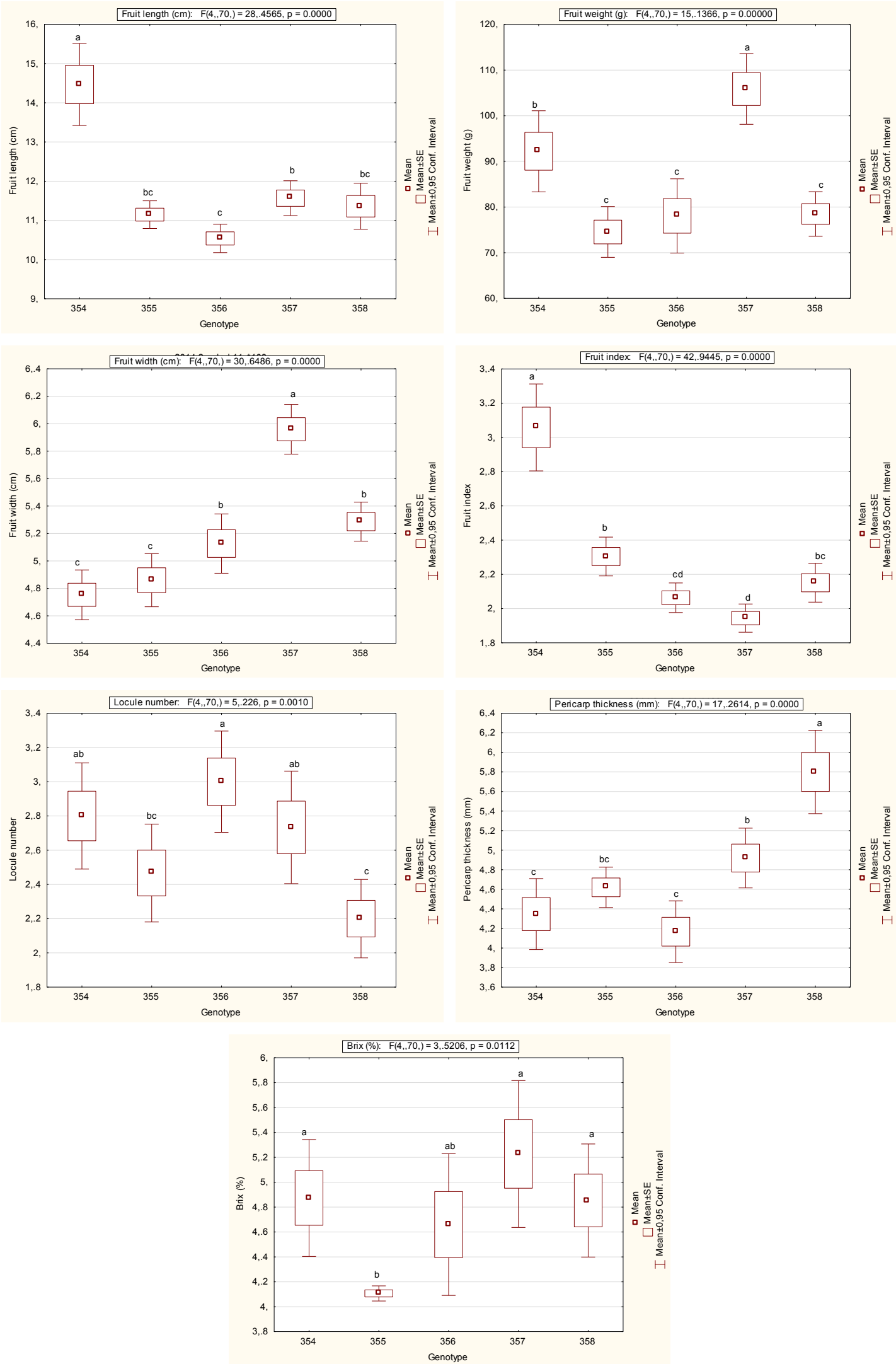

Figure 2. Fruit characteristics of the evaluated genotypes

$*$ different letters show significant differences between genotypes $(P<0.05)$ according to Duncan's test. 
Table 2. Coefficient of variation (\%) for the evaluated traits in pepper genotypes

\begin{tabular}{ccccccrr}
\hline Genotype & Fruit weight & Fruit length & Fruit width & Fruit index & Locule number & Pericarp thickness & TSS \\
\hline 354 & 17.40 & 13.07 & 6.88 & 14.99 & 20.02 & 17.08 & 8.07 \\
355 & 13.49 & 5.71 & 7.20 & 8.88 & 20.94 & 17.82 & 2.68 \\
356 & 18.80 & 6.19 & 7.61 & 7.55 & 7.68 & 13.69 & 11.22 \\
357 & 13.22 & 6.94 & 5.49 & 9.51 & 18.82 & 13.28 \\
358 & 11.24 & 9.33 & 4.84 & & & 16.90 \\
\hline
\end{tabular}

Positive correlation was recorded between fruit weight and TSS, while Lannes et al. (2007) showed the negative correlation. Although there was no difference in yield among the genotypes in our study, some evaluated traits could be very important in relation to yield. According to Cankaya et al. (2010), fruit wall thickness and fruit width should be used as traits of increasing yield per plant. Vani et al. (2007) found that the number of fruits per plant and fruit diameter are major contributors to pepper yield. In our study, positive correlation was found between fruit weight and all other tested traits of the fruit. Therefore, further increase of these traits will probably lead to increased yield. According to the results of Rêgo et al. (2011), fruit width, fruit weight and dry matter content were positively correlated with the yield.

Fruit width was the trait which had the lowest CV and it ranged from 4.84 to 7.6 (Table 2). Similar results were reported by Todorova (2007), because between fruit length, weight, width and pericarp thickness, the lowest CV was found in fruit width. Higher CV for all traits was found in parental line 354 especially for fruit length, fruit index and pericarp thickness. This high CV might indicate possibilities that this parent line could develop more progenies with different fruits characteristic. Genotypes 356 and 357 had the highest CV for TSS (22.05\% and 20.38\%, respectively), which could be used for improving this trait to higher level in the following generations.

\section{Conclusion}

According to this study, pepper plants originating from open pollination could be an interesting source of new variability. Based on the evaluated traits, genotype 357 will be used for further selection because of higher fruit weight, and genotype 358 because of a thicker pericarp.

\section{References}

Bharadwaj, D.N., Singh, H., \& Yadav, R.K. (2007). Genetic variability and association of component characters for yield in chilli (Capsicum annum L.). Progressive Agric, 7(1-2), 72-74.

Cankaya, S., \& Kayaalp, G.T. (2007). Estimation of relationship between live weights and some body measurements in German farm $\times$ hair crossbred by canonical correlation analysis. I Anim Prod, 48(2), 27-32.

Cankaya, S., Balkaya, A., \& Karaagac, O. (2010). Canonical correlation analysis for the determination of relationships between plant characters and yield components in red pepper [Capsicum annuum L. var. conoides (Mill.) Irish] genotypes. Span J Agric Res, 8(1), 6773. doi:10.5424/sjar/2010081-1144

Cruz, D.O., Freitas, B.M., Silva, L.A., Silva, E.M.S., \& Bonfim, I.G.A. (2005). Pollination efficiency of the stingless bee Melipona subnitida on greenhouse sweet pepper. Pesqui Agropecu Bras, 40,1197-1201.

Geleta, L.F., Labuschagne, M.T., \& Viljoen, C.D. (2005). Genetic Variability in Pepper (Capsicum annum L.) Estimated by Morphological Data and Amplified Fragment Length Polymorphism Markers. Biodiversity and Conservation, 14(10), 23612375. doi:10.1007/s10531-004-1669-9

Greco, M.K., Spooner-Hart, R.N., Beattie, A.G.A.C., Barchia, I., \& Holford, P. (2011). Australian stingless bees improve greenhouse Capsicum production. J Apic Res, 50, 102-115.

IPGRI, AVRDC, \& CATIE. (1995). Descriptors for Capsicum (Capsicum spp.). Rome, Italy: International Plant Genetic Resources Institute; Taipei, Taiwan: Asian Vegetable Research and Development Center; Turrialba, Costa Rica: Centro Agronómico Tropical de Investigación y Enseñanza.

Lannes, S. D., Finger, F. L., Schuelter, A. R., \& Casali, V. W. D. (2007). Growth and quality of Brazilian accessions of Capsicum chinense fruits. Sci Hortic, 112, 266-270. doi:10.1016/ j.scienta.2006.12.029

Lefebvre, V., Palloix, A., \& Rives, M. (1993). Nuclear RFLP between pepper cultivars (Capsicum annuиm L.). Euphytica, 71, 189-199. doi:10.1007/BF0004040

Lefebvre, V., Goffinet, B., Chauvet, J.C., Caromel, B., Signoret, P., Brand, R., \& Palloix, A. (2001). Evaluation of genetic distances between pepper inbred lines for cultivar protection purposes: Comparison of AFLP, RAPD and phenotypic data. Theoretical and Applied Genetics, 102(5), 741-750. doi:10.1007/ s001220051705

Rêgo, E. R., Rêgo, M. M., Finger, F. L., Cruz, C. D., \& Casali, V. W. D. (2011). Phenotypic diversity, correlation and importance of variables for fruit quality and yield traits in Brazilian peppers (Capsicum baccatum). Genet Resour Crop Evol, 58, 909-918. doi:10.1007/s10722-010-9628-7

Serrano, A. R., \& Guerra-Sanz, J. M. (2006). Quality fruit improvement in sweet pepper culture by bumblebee pollination. Sci Hortic, 110, 160-166.

Smith, R. P., \& Basavaraja, N. (2005). Variability and correlation studies in chilli (Capsicum annuum L.). Karnataka J Agric Sci, 19(4), 888-891.

Tang, H., Sezen, U., \& Paterson, A. H. (2010). Domestication and plant genomes. Curr. Opin. Plant Biol., 13(2), 160-6.

Todorova, V. (2007). Fruit Characterization and Influence of Variation Factors in Pepper Kapiya Type Varieties and Breeding Lines (Capsicum annuum L.). Bulg J Agric Sci, 13, 309-315.

Vani, S. K., Sridevi, O., \& Salimath, P. M. (2007). Studies on Genetic Variability Correlation and path analysis in Chilli (Capsicum annum L.). Annu. Biol. 23(2), 117-121. 


\section{Karakteristike plodova paprika poreklom iz slobodne oplodnje}

\section{Dario Danojević · Slađana Medić-Pap · Aleksandra Savić · Janko Červenski}

Sažetak: Paprika je jedna od značajnijih povrtarskih vrsta u Srbiji. U pojedinim regionima naše zemlje potrošači su navikli da konzumiraju plodove različitog oblika, veličine i boje. Cilj ovog rada je da se ispitaju 4 genotipa paprike (355, 356, 357 i 358) kraćih plodova poreklom iz slobodne oplodnje, poredeći ih sa ishodnom majčinskom linijom 354 dužih plodova. Na plodovima iz druge berbe izmerena su sledeća svojstva: dužina, širina i masa ploda, broj komora, debljina perikarpa, sadržaj suve materije i prinos plodova po biljci. Indeks ploda je izračunat na osnovu odnosa dužine i širine ploda. Podaci su obrađeni u programu Statistica 12, metodom analize varijanse, koristeći Dankanov višestruki test intervala na nivou značajnosti 0,05 . Između ispitivanih genotipova nije bilo značajnih razliku u prinosu plodova po biljci. $\mathrm{Na}$ osnovu izmerenih svojstava, genotip 357 će biti korišten za dalji selekcioni rad zbog veće mase ploda, a genotip 358 zbog debljeg perikarpa.

Ključne reči: debljina perikarpa, dužina ploda, genotipovi, karakteristike plod, paprika, slobodna oplodnja 